\title{
ArcheoSciences
}

Revue d'archéométrie

\section{The Phoenician gold jewellery from Kition, Cyprus}

L'orfèvrerie phénicienne en or de Kition, Chypre

\section{Pavlos Flourentzos and Maria Luisa Vitobello}

\section{(2) OpenEdition}

\section{Journals}

Electronic version

URL: https://journals.openedition.org/archeosciences/2135

DOI: 10.4000/archeosciences.2135

ISBN: 978-2-7535-1598-7

ISSN: 2104-3728

Publisher

Presses universitaires de Rennes

Printed version

Date of publication: 31 December 2009

Number of pages: 143-149

ISBN: 978-2-7535-1181-1

ISSN: $1960-1360$

\section{Electronic reference}

Pavlos Flourentzos and Maria Luisa Vitobello, "The Phoenician gold jewellery from Kition, Cyprus",

ArcheoSciences [Online], 33 | 2009, Online since 10 December 2012, connection on 01 February 2022.

URL: http://journals.openedition.org/archeosciences/2135 ; DOI: https://doi.org/10.4000/

archeosciences. 2135 


\title{
The Phoenician gold jewellery from Kition, Cyprus L'orfêvrerie phénicienne en or de Kition, Chypre
}

\author{
Pavlos Flourentzos* and Maria Luisa Vitobello**
}

\begin{abstract}
In 1998, a built tomb was excavated on the southern outskirts of the town of Larnaca. The tomb was labelled MLA 1742 and included a unique collection of jewellery that likely adorned the deceased. Their assemblage totalled twenty three pieces belonging to various jewellery typologies, manufactured in gold and ornate with semi-precious stones. The tomb shows several ritual similarities with the famous Royal Tombs of Salamis. It can be suggested that a member of the Kition Phoenicians' upper classes was buried here, possibly even a member of the royal family of this city. The tomb is dated to a period around the end of the $8^{\text {th }}$ century BC, when Cyprus was under a strong orientalising influence, due in all probability to the presence of Phoenician settlers in Kition. Various goldsmithing techniques, such as granulation, cloisonné, etc., were applied in the production of artefacts. Some of the jewellery typologies are quite rare or even unique. The rings and swivel rings found in the tomb show a strong Egyptian influence, revealed in the decorative representation of various Egyptian deities and other Egyptian motifs.

The variety of the jewellery and their well-known find spot provided the opportunity to study the hoard and gather more precise data that will facilitate the investigation of similar artefacts in the future. A pilot study, reported in this volume by Guerra and Rehren, within the AUTHENTICO research project activities was carried out on some of the artefacts, showing the high caratage of the gold alloys used in the fabrication of the jewellery.

Résumé : En 1998 une tombe a été fouillée dans la banlieue sud de la ville de Larnaca. La tombe, référencée MLA 1742, comprenait un ensemble unique d'orfevrerie de parure du défunt. L'ensemble était constitué de vingt-trois pièces de typologies diverses, fabriquées en or et ornées de pierres semiprécieuses. La tombe présente plusieurs signes de rituels comparables à ceux des fameuses Tombes royales de Salamis. Nous pouvons suggérer qu'un membre de la haute société phénicienne de Kition y était enterré, voire même un membre de la famille royale de la cité. La tombe est datée de la fin du viIr siècle av. J.-C. quand Chypre se trouvait sous une forte influence orientalisante, attribuable selon toute probabilité à la présence de colons Phéniciens à Kition. Plusieurs techniques orfevres, telles la granulation, le cloisonné, etc., ont été utilisées pour la production de ces pièces d'orfevrerie. Certaines typologies de ces pièces sont très rares, voire uniques. Les anneaux et les bagues pivotantes trouvés dans la tombe présentent une forte influence égyptienne, révélée par les représentations de différentes divinités Egyptiennes et de motifs égyptiens. La variété de l'orfevrerie et leur célèbre lieu de découverte ont fourni l'opportunité d'étudier ce dépôt et de rassembler des données exactes qui faciliteront les recherches dans l'avenir sur des objets similaires. Une étude pilote, dans le cadre des activités de recherche du projet AUTHENTICO et présentée dans ce volume par Guerra et Rehren, a été menée sur cette orfevrerie permettant de montrer la haute qualité des alliages d'or utilisés pour fabriquer les pièces.
\end{abstract}

Keywords: cloisonné, Cyprus, fibula, granulation, jewellery, Phoenicia, Kition.

Mots-clés : cloisonné, Chypre, fibule, granulation, orfevrerie, Phénicie, Kition.

\section{INTRODUCTION}

Kition was one of the most important kingdoms of Cyprus, located in the south-eastern part of the island
(Fig. 1) and hosting one of the most significant hoards in Cyprus dating from Antiquity. The ancient town has a Mycenaean pre-history; however, it also flourished since the $9^{\text {th }}$ century BC, when an important tribe of traders and

*Department of antiquities - 1, Museum Avenue, 1516 Nicosia, Cyprus. (pflourentzos@da.mow.gov.cy)

** EJTN GEIE - 124, Rue du Commerce, B-1000 Brussels, Belgium. (info@ejtn.org) 


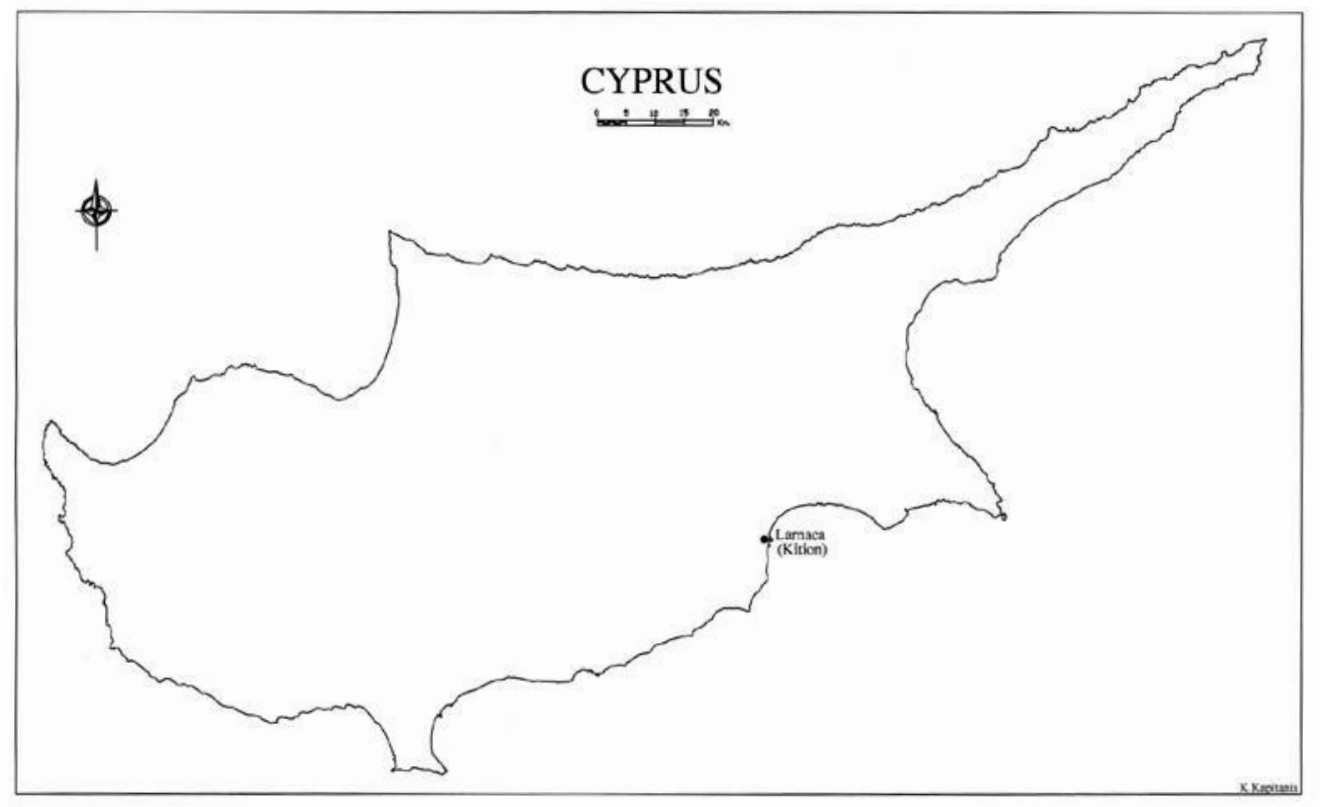

Figure 1: Map of Cyprus with the localisation of Larnaca.

Figure 1: La carte de Chypre avec la localisation de Larnaca.

seafarers came to colonize the area. Those seafarers were of course Phoenicians, originally from the famous city of Tyre in the Levant (Geling and Viemer, 1990).

Since the Ancient and Classical periods ( $8^{\text {th }}$ to $5^{\text {th }}$ century BC), a Phoenician dynasty ruled Kition. In 1998, an isolated built tomb - as it was not part of a wider necropolis - of monumental architecture was excavated in the south-western outskirts of modern Larnaca (Fig. 2). The tomb had a chamber and a dromos where sacrifices of horses were exposed, with bronze components from the horses' harnesses. Inside the tomb, due to great amount of water flowing in throughout the centuries, completely deteriorated bones were found (Hadjsawas, 2000; Karageorghis, 1976).

Apart from the jewellery that is presented below, various vessels imported from Phoenicia were also found. An amphora showing a unique decoration, which was closed with a lid, deserves special attention. The jewellery consists of various types of pendants and beads (part of a necklace or necklaces), earrings, bracelets, rings and a unique gold fibula (Pierides, 1971).

\section{EARRINGS}

Five earrings were found: all of them belong to the boat or leech shape typology, and are forged from a single piece of solid cast gold, hammered and shaped as a crescent. One end of the crescent extends to form the hanging hoop from which the hook is tapered, smoothed out into a fine needle for insertion into the ear.

\section{RiNGS}

Three rings of solid gold were discovered in the tomb. The first one (MLA 1742/1) is a gold ring with an ivory intaglio bezel. The hoop and the bezel were worked separately; the ring is made of a single piece of solid gold, cast in a mould, while the hoop's surface is roughly finished by burnishing. The upper side of the hoop has an elliptical bezel, bearing a separate seal device. The sphragistic device, broken into three pieces, is engraved with the representation of an ibis standing on its side, while the background is filled with crossed lines representing bamboo or papyrus.

The second one (MLA 1742/2) is a gold ring with an indigo (sodalite) intaglio gem. The artefact shows an identical structure and manufacturing techniques to the previous ring, also having an elliptical bezel with a removable seal device. The sphragistic device is engraved and depicts the Egyptian goddess of life Maat with a feather. The goddess Maat was the personification of the basic laws of all existence; she embodied the concepts of law, truth and world order. In the Egyptian tradition, judges were regarded as priests of Maat.

The third object (MLA 1742/3) is also a gold ring with faience intaglio. The manufacturing techniques are similar to those already mentioned above; the seal, however, is not removable, possibly to withstand daily use. Another interesting feature of this ring is that the intaglio, broken and partly worn, possibly depicts an ibis and a feather. 


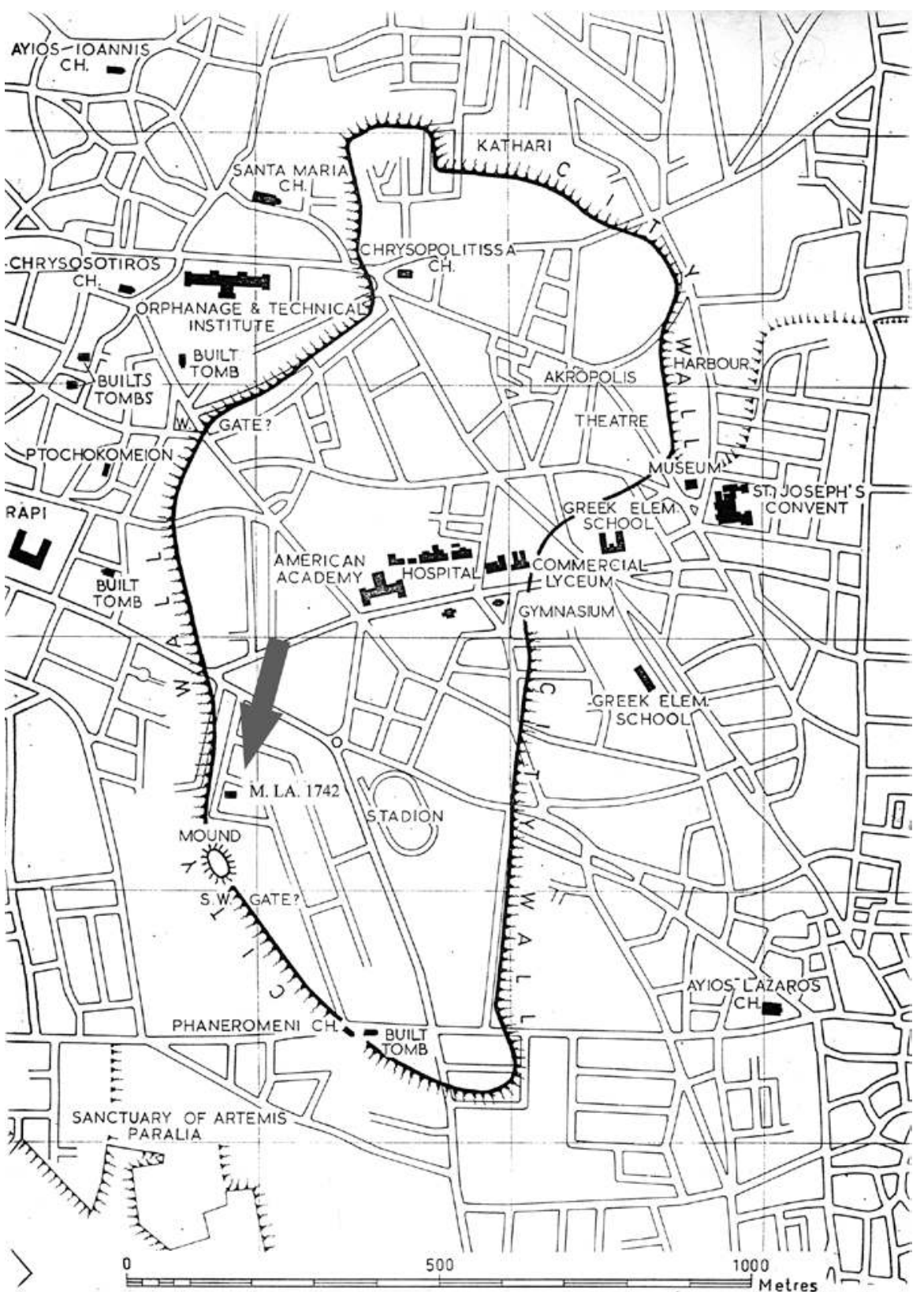

Figure 2: The localisation of the Phoenician tomb of Kition in modern Larnaca.

Figure 2: La localisation de la tombe phénicienne de Kition dans la ville moderne de Larnaca.

\section{Bracelets}

The tomb also yielded two unique bracelets. The first one (MLA 1742/18) (Fig. 3) consists of two parts: a ribbon bracelet and a circular box setting, holding a discoid cabochon agate, having at the centre an eye reminiscent of the eye of Horus, having an apotropaic significance in ancient tradition. The stone is set into a box setting, the sides of which and top frame are granulated. The strap consists of a ribbon obtained from four parallel double loop-in-loop chains, threaded through by additional loops linking the chains and forming the braided strap up to the desired length. At both ends of the ribbon, the finials have their loops extended by approximately $25 \mathrm{~mm}$ to provide hinges through which pivots connect the ribbon to the box setting. The box setting is decorated with a row of granules and alternating granulated triangles; a row of granules runs along the full length of the side; a border of round wire encircles the entire side below, with an additional double braided wire above the round wire. A thin top plate is fused to a cylinder forming the outer wall of the box; starting from the outer edge, the centre frame is decorated with a circle of round wire and a 


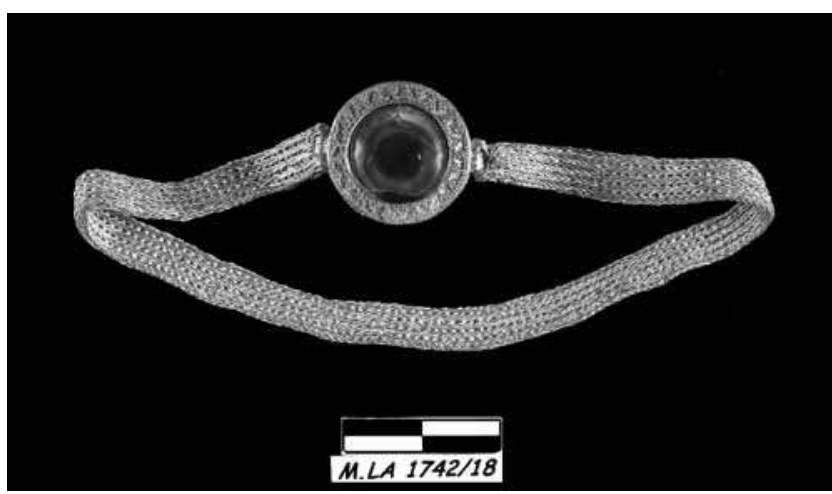

Figure 3: (See colour plate) The bracelet from the tomb of Kition with circular box setting holding a discoid cabochon agate, reference MLA 1742/18.

Figure 3 : (Voir planche couleur) Le bracelet de la tombe de Kition possédant une monture circulaire contenant une agate en cabochon, référence MLA 1742/18.

row of granules alternating with granulated triangles pointing inward towards the centre of the box. A second row of granules, showing granulated triangles pointing outward from the centre and a circlet of round wire, delimitates the inner border of the frame. On both sides of the box, diagonally opposed, tiny cylinders obtained from coiled wires form the hinges through which the pivots are inserted to connect the ribbons' hinges to the box setting.

From a technical and an artistic point of view, this bracelet is extremely attractive and rare; if considering the manufacturing techniques, the combination and refinement of the applied competences and skills of the ancient craftsman that fabricated this artefact render it more than exceptional worldwide.

The second bracelet (MLA 1742/19) (Fig. 4) is manufactured with an entirely different technique. It consists of a quadruple loop-in-loop chain, with a wire diameter of $0.4 \mathrm{~mm}$ and a chain length of $180 \mathrm{~mm}$. At both ends of the chain, an inner tapering wire pivot is inserted through the scarab's suspension-hole to allow swivelling; the wire is wound into and around the bracelet's final loops, coiled fourfold around itself to secure the scarab. The scarab is set inside an elliptical bezel, with its sides smoothly rounded off at both ends, two globules (recalling dung balls) holding the scarab. The globules are embossed, and joined to the bezel by fusing. Both globules show a round hole in the lower part, to allow the connecting tapered wire to pass through. The scarab is carved both on the soft round top and flat on the backside, and its surface is decorated with an inscription showing Egyptian hieroglyphics: on its lower part, two goddesses seated side by side and three 'beathyls' topped by a cartouche. The cartouche is typically evidence of objects often associated with the Pharaoh.

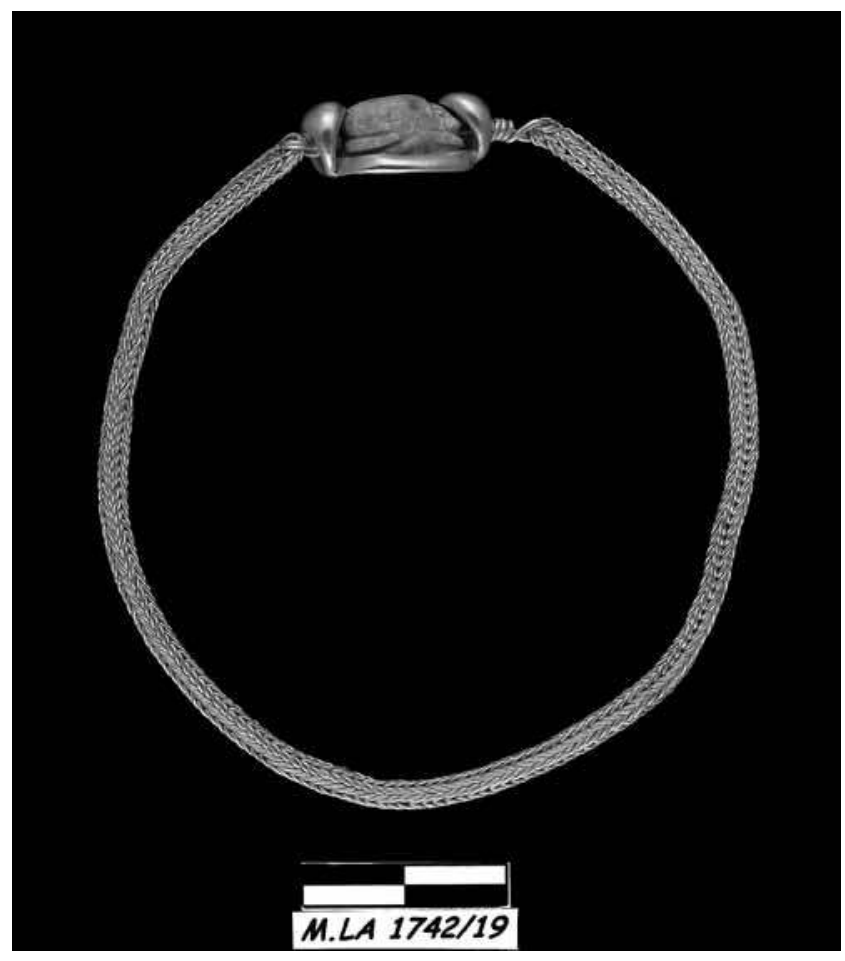

Figure 4: (See colour plate) The bracelet from the tomb of Kition with a scarab and a quadruple loop-in-loop chain, reference MLA 1742/19. Figure 4: (Voir planche couleur) Le bracelet de la tombe de Kition avec un scarabée et une chaîne en quadruple loop-in-loop, référence MLA 1742/18.

\section{THE NECKLACE}

Another important find is an extraordinary necklace consisting of seventeen beads and pendants of various shapes and significances. The gold elements of the necklace are obtained from high carat natural gold alloy, an aspect confirmed by further characterization (Guerra and Rehren, 2009). One of these is a gold sheet disc (MLA 1742/25) (Fig. 5) made of beaten gold sheet and framed by a round wire edge fused onto it. A large granule is positioned in the centre of the disc. Such a disc is a diagnostic symbol of the goddess Astarte, often represented ornate with a crescent, the goddess' symbol.

Three beads of this necklace (MLA 1742/34, 6, 7) are spherical, made of high carat gold alloy, and obtained by joining two hemispheres, each one embossed out of thick plate. The joining of the two halves is clearly outlined by magnification. The upper hemisphere is pierced at the top, where a small round suspension loop is inserted and fused.

In addition, there are also two acorn-shaped beads made of high carat gold alloy (MLA 1742/30, 9), obtained by the same technique described above; the upper hemisphere is 


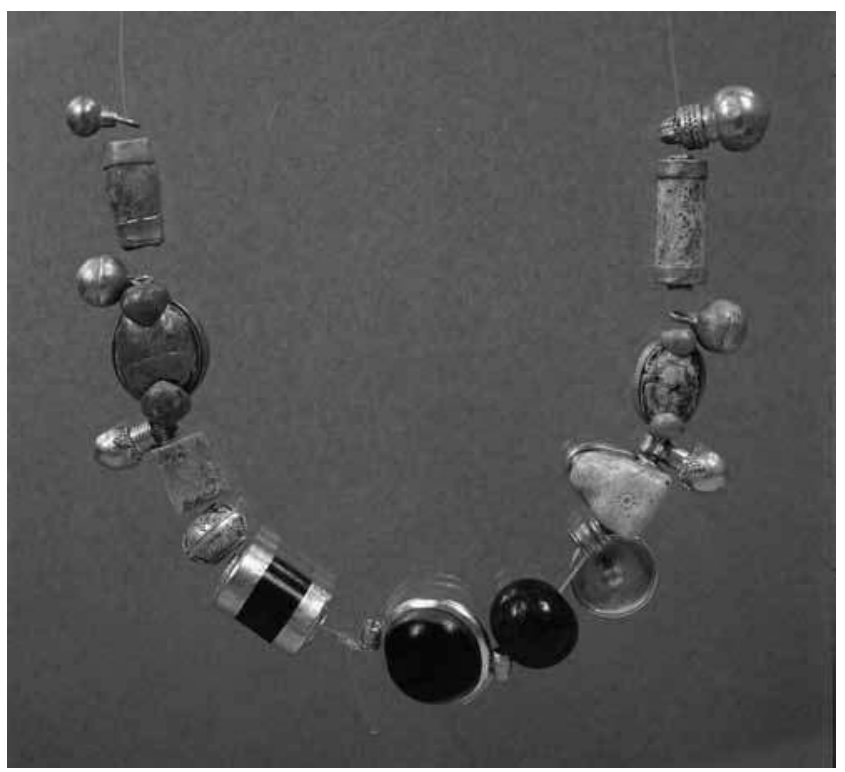

Figure 5: (See colour plate) Mounting proposal for the necklace of Kition, containing seventeen beads and pendants of various shapes. Figure 5: (Voir planche couleur) Proposition de montage du collier de Kition, consistant en dix-sept perles et pendentifs de formes variées.

bordered by a row of granules from which three granulated triangles pointing downwards provide additional decoration.

The necklace also consists of four cylindrical beads (MLA 1742/17, 28, 31, and 32). Three beads (numbers 28, 31, 32) are made from marble and agate, pierced longitudinally and fitted at both ends with gold sheet finials. The other one, no. 17, is made from ivory, is plain and does not bear golden sheet finials.

Another element of the necklace is a plain spherical agate pierced through (MLA 1742/33).

An additional outstanding bead (MLA 1742/29) is executed in a stone - probably marble - representing a bull's protome, delicately carved to enhance the eyes, nose, and ears: the forehead is decorated with the Astarte sun disc, represented by carved dots. The bezel which surrounds the bead is obtained from gold sheet; two decorative rows of round wire and a central row of braided wire are positioned and fused along the lower side of the bezel, encircling the seal; both bead and bezel are pierced through in the top part to allow threading, while the two opposed holes are bordered by two round loops. The height of the pendant allows for an engraved back side seal representing a goddess with uplifted arms.

Two scarabs (MLA 1742/4, 5) represent further elements of the necklace. No. 4 consists of an engraved faience scarab, pierced longitudinally for suspension. On each side of the opening, two globules (dung balls), obtained by embossing thin gold plate, are fused to the bezel, holding the jewel. The high bezel is made of gold sheet; the scarab's backside seal is engraved, showing centred on the surface an alabaster bottle, flanked by two C-shaped ornaments and, on the outer edge, on both sides, two ankhs symbols are engraved.

The other scarab (no. 5) is quite unique in its conception; it is composed of two superimposed elements: a scarab, obtained from embossed gold sheet, with delicate features reproducing the animal's details, is positioned over a back seal stone, in turn set into a golden bezel. The entire upper gold surface of the embossed scarab has a patina, the origin of which needs further investigation. The back side seal, positioned under the golden carapace, is also carved, showing probably a hieroglyphic symbol flanked by two feathers.

Finally, the necklace has two other golden beads. The first (MLA 1742/16) is made of gold alloy, possibly representing a vase; the body is topped by a cylindrical neck, its upper part decorated with one loop of round wire, one loop of braided wire (two twisted wires facing opposite direction), and another loop of round wire; the wires are fused onto the neck surface.

The second bead (MLA 1742/8) has a lentoid shape, and is obtained from two hemispheres of embossed gold sheet; the bead is open on both sides to allow threading; both sides of the opening are bordered by rows of granules. Along the circumference, two rows of granules define each hemisphere; along each row, six granulated triangles, alternating with six granulated lozenges, decorate both the upper and the lower hemisphere of the bead.

\section{The fibula}

The gold fibula (MLA 1742/20) (Fig. 6) is obtained from a single gold rod, skilfully forged to the desired triangular shape, which recalls an inverted bow. The bow is pinched at the top into a loop from which both sides extend and are elegantly shaped into inverted curves; on one side, the body flows into the coiled spring, and then tapers into the needle; on the other side, the body is forged shaped into the foot and catch plate. This typology of fibula is defined as an inverted bow-shaped fibula (Gjerstad, 1948). As decorative elements, three cloisonné rosettes are positioned on the top and on both sides of the fibula. The Egyptian influence of these particular elements is worth mentioning: similar rosettes decorate the head-dress of an Egyptian lady from the court of Tuthmosis III, $18^{\text {th }}$ Dynasty, 1450 BC, Thebes (Heiniger and Heiniger, 1974). 


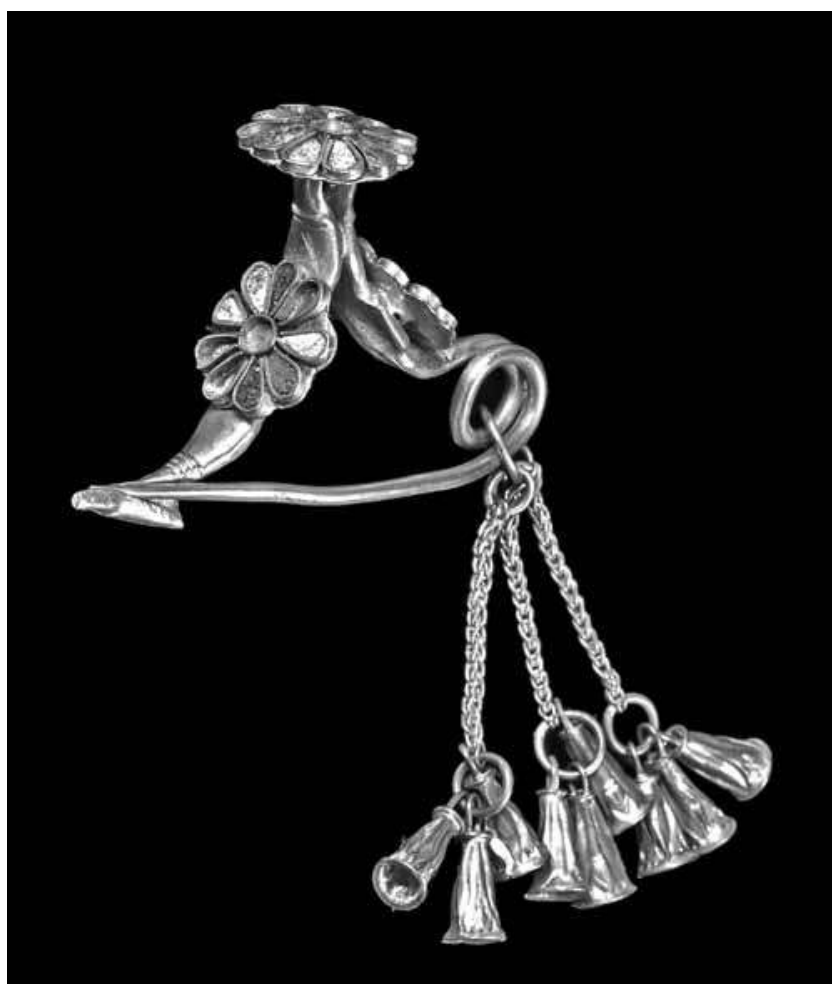

Figure 6: (See colour plate) The unique inverted bow-shaped gold fibula of Kition, reference MLA 1742/20.

Figure 6: (Voir planche couleur) L'unique fibule en or à l'arc inverse de Kition, référence MLA 1742/20.

The top rosette is eleven-petalled, the right rosette (facing the coil) is ten-petalled, while the left rosette (facing the catch-plate) is nine-petalled. Each rosette is obtained from gold sheet, strips of which form the cloisons. The cloisons outline the petals, which are filled with polychrome enamels of various colours. Additional decorative elements of the artefact are double loop-in-loop chains linked to the coiled spring: from each chain, connected by means of suspension rings, three delicately chiselled bells, recalling stylized lotus buds, are hanging. A further extraordinary feature of this fibula is an alef (a Phoenician letter) engraved on the front side, above the rosette, probably representing the initial letter of the owner's name. During the Late Cypro-Geometric and Early CyproArchaic period (circa 850-700 BC) this type of fibulae were mostly made of bronze; the shape is typically and diagnostically Cypriot, often found in tombs of the above mentioned period all over the island. Very rarely, this type of fibula is made of silver: the fibula from the Kition-Larnaca built tomb no. 1 thus represents a golden work of art of exceptional importance for Cypriot and world heritage.

Preliminary to a final publication which will reconstruct the excavation's context and methodology, some introduc- tory content is provided in this paper, aiming to position the artefact within its historical and archaeological context.

The fibula's main body, of irregular triangular shape, can easily be referred to Type 4b (Fig. 7) of the Cypriot fibulae, according to the criteria already presented by the Swedish Cyprus Expedition (Gjerstad, 1948: 145, Fig. 26, Bronze, $4 \mathrm{a}$ and $4 \mathrm{~b}$ ) and further confirmed by the typological analysis (Stronach, 1959); it represents an original Cypriot type.

The chronological horizon appears to be clearly established around the $8^{\text {th }}-7^{\text {th }}$ century BC (Cypro-Geometric period), tending to a lower dating of such a chronology. This typology is common in the Syro-Palestinian area, and in the Anatolian and Aegean environments, especially Rhodos and Aegina.

Characteristic features of the Kition fibula are the addition of three chains and lotus bud pendants, and, above all, the exceptional enrichment of three cloisonné rosettes to the main body, enhanced by polychrome enamel cloisons, which are placed two at the centre of each of the fibula's arms, and one at the top of the fibula's apex, respectively.

With their curved shape, both of the fibula's arms appear to recall the Egyptian solar boat: this appears evident in the bows' shapes, which meet towards the apex with an elegant decorative effect, while the two rosettes, topping both arms, are placed in the area where the cabin is usually located.

Such a tendency to use Egyptian or Egyptianizing elements or symbolism in such an eclectic and audacious way is a typical and founding aspect of Phoenician art, of which the Kition fibula is certainly one of the most original and uncommon examples (Ciafaloni, 1995). Not only in jewellery, but also in glyptic arts (i.e. on a chalcedony scarab at the Louvre Museum) and in ivories (Herrmann, 1986: nn. 989-994, Pls. 2255-2257), the solar boat symbolism is widely asserted, and represented in numerous and ingenuous variations with respect to the classical Egyptian interpretation.

Phoenician sumptuous objects had a widespread diffusion with all Mediterranean elites, in this particular instance in
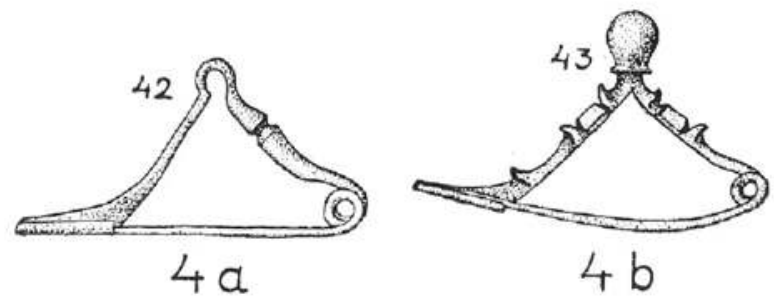

Figure 7: The elbow fibula of type 4 from Stronach (1959). Figure 7: La fibule à l'arc coudé de type 4 de Stronach (1959). 
its oriental area, in the chronological span already identified, and in particular in Cyprus, as shown by the example of the so-called Cypro-Phoenician bowls (Markoe 1985), which constitute the most evident manifestation of such an eclectic trend.

Within the Levantine and Cypriot environments, the Phoenician craft was permeated with Mesopotamian and Near-Eastern influences; in fact, it can probably be inferred that it shares an ample aesthetic and technical Koiné only partially known.

Notwithstanding this aspect, the extraordinary recent discovery of the Nimrud Queens Tombs (Damerji, 1999) has added an impressive quantity of artefacts to the meagre evidence related to Mesopotamian jewellery from the first millennium BC.

As an example, cloisonné and champlevé techniques are widely exemplified by the application of enamels and semiprecious stone inlays on sumptuous bracelets (Damerji, 1999: Abb. 27-30), known until now only from relief reproductions of neo-Assyrian palaces.

It then appears that not only Egypt should be taken into consideration as a source of the decorative technique applied on the rosettes, even if, since the New Kingdom period, there are undoubtedly copious testimonials of floral elements characterized by these techniques in Egypt (see the head-dress of one of Tutmosis III's wives from Thebes, now at the Metropolitan Museum of Art, New York), as well as in a Mycenaean setting (Demakopoulou, 1988).

To conclude, it could be stated that, in the Kition fibula, the corpus of Egyptianizing elements generally recalling the religious world steers towards an eschatological and symbolic interpretation of the artefact, possibly destined, since its creation, for a real use in everyday life, to be worn by a prince or a member of the Kition aristocracy, as well as for funerary use.

Furthermore, the rosette motive in the Mesopotamian area appears linked to the major oriental female goddess Ishtar/ Astarte, i.e. in neo-Assyrian setting, chronologically parallel $\left(8^{\text {th }}\right.$ century $\left.\mathrm{BC}\right)$ to the Kition fibula: cloisonné rosettes appear on a bracelet from the above mentioned Nimrud Queens Tombs (Damerji, 1999: Abb. 30), where the same goddess is represented in the bracelet centre-plate. Taking into account the eclectic and syncretic orientation of the Phoenician culture already identified above, it is possible to assume that both sources, the Egyptian and Mesopotamian, efficiently merge into a certainly unique artefact.

\section{Acknowledgements}

With thanks to Prof. Davide Ciafaloni, Università di Milano Bicocca, Italy, for his collaboration and contribution concerning the humanistic aspects of the research on the Kition fibula.

\section{References}

Ciafaloni, D., 1995. Iconographie et Iconologie, in V. Krings (ed.), La civilisation phénicienne et punique. Manuel de recherche. Leiden: Brill, 535-549.

Culican, W., 1966. The first merchant venturers: the ancient Levant in history and commerce. London, Thames \& Hudson.

DAMERJ, M.S.B., 1999. Gräber assyrischer Königinnen aus Nimrud. Mainz, Verlag des Römisch-Germanischen Zentralmuseums.

Demakopoulou, K. (ed.), 1988. The Mycenaean World: Five Centuries of Early Greek Culture, 1600-1100 BC. Athens: Ministry of Culture, National Hellenic Committee (ICOM).

Geling, U. and Viemer, H.G., 1990. Die Phoenizier in Zeitalter Homer. Mainz.

GJerstad, E., 1948. The Cypro-Geometric, Cypro-Archaic and Cypro-Classical Periods. The Swedish Cyprus Expedition, Vol. IV, part II, Arts \& Crafts. Stockholm, The Swedish Cyprus Expedition.

Guerra, M. F. and Rehren, Th. 2009. In-situ examination and analysis of the gold jewellery from the Phoenician tomb of Kition (Cyprus), ArcheoSciences 33.

Hadjisavvas, S., 1999. Chronique de fouilles et decouvertes archeologique à Chypre. In $\mathrm{BCH}$ (123).

Heiniger, E.A. and Heiniger, J., 1974. The Great Book of Jewels. Boston, New York Graphic Society.

HerrmanN, G., 1986. Ivories from room SW37 Fort Shalmanesher. London, British School of Archaeology in Iraq.

Karageorghis, V., 1976. Kition Mycenaen and Phoenician discoveries in Cyprus. London, Thames \& Hudson.

Marкoe, G., 1985. Phoenician Bronze and Silver Bowls from Cyprus and the Mediterranean. Berkeley, CA, University of California Press.

Moscati, S., 1988. The Phoenicians, Milan.

Pierides, A., 1971. Jewellery in the Cyprus Museum. Nicosia, Republic of Cyprus, Ministry of Communications and Works, Department of Antiquities.

Stronach, D., 1959. The Development of the Fibula in the Near East. Iraq 21: 180-206. 
